\title{
A novel elevated temperature pre-treatment for electrochemical capacity enhancement of graphene nanoflake-based anodes
}

\author{
Sandeep Bhattacharya ${ }^{1}$ D . Ahmet T. Alpas ${ }^{1}$ D
}

Received: 22 November 2017 / Accepted: 2 February 2018 / Published online: 16 February 2018

(c) The Author(s) 2018. This article is an open access publication

\begin{abstract}
Improvements in the specific capacity of graphene nanoflake-based anodes cycled vs. $\mathrm{Li}^{-} \mathrm{Li}^{+}$were investigated at two cycling temperatures of 25 and $50{ }^{\circ} \mathrm{C}$. When cycled at $25^{\circ} \mathrm{C}$, the first cycle specific capacity of the graphene nanoflakes was 636 $\mathrm{mA} \mathrm{h} \mathrm{g}{ }^{-1}$, whereas cycling at $50{ }^{\circ} \mathrm{C}$ led to a $35 \%$ increase in the specific capacity to $856 \mathrm{~mA} \mathrm{~h} \mathrm{~g}^{-1}$. High resolution SEM investigations revealed that the increased capacity of graphene cycled at $50{ }^{\circ} \mathrm{C}$ was accompanied by the formation of a uniform and continuous solid electrolyte interface (SEI). The strain generated in graphene anodes was reduced from $0.75 \%$ at $25{ }^{\circ} \mathrm{C}$, to $0.12 \%$ at $50{ }^{\circ} \mathrm{C}$, as determined by in situ Raman spectroscopy. This was attributed to the reduction in the extent of solvent co-intercalation at $50^{\circ} \mathrm{C}$. The results suggest that pre-cycling of $\mathrm{Li}$-ion cell anodes containing graphene flakes at elevated temperatures would increase their specific capacity at the same charging/discharging current densities as that used for cycling at room temperature.
\end{abstract}

Keywords Graphene nanoflakes $\cdot$ Li-ion battery $\cdot$ SEI $\cdot$ Temperature $\cdot$ Rate $\cdot$ Capacity

\section{Introduction}

The performance of a Li-ion battery largely depends on the structures and properties of its electrodes. The crystal structure of graphite corresponds to a stacking of hexagonal networks of individual layers in the direction perpendicular to the layer plane ( $c$-axis) following an A-B stacking arrangement [1]. Lithium intercalation in between the graphene layers leads to the formation of $\mathrm{LiC}_{6}$, which results in a low theoretical capacity of graphite that is $372 \mathrm{~mA} \mathrm{~h} \mathrm{~g}^{-1}$. Although graphite anodes provide good life cycle performance and high coulombic efficiency [2, 3], they suffer from severe damage in the first cycle due to lithiation and solvent co-intercalation that leads to a drastic drop in the specific capacity $[4,5]$. Once a solid electrolyte interphase (SEI) is formed on the electrode surfaces, solvent co-intercalation and, hence, damage is reduced $[4,6]$ depending on the morphology and uniformity of the SEI [6].

Ahmet T. Alpas

aalpas@ uwindsor.ca

1 Engineering Materials Program, Department of Mechanical, Automotive and Materials Engineering, University of Windsor, 401 Sunset Avenue, Windsor, ON N9B 3P4, Canada
Graphene consists of $s p^{2}$ carbon hexagonal networks in which strong covalent bonds are formed between two adjacent carbon atoms [1]. It is argued that for a single graphene layer, lithium could be adsorbed on both sides of the sheet surfaces resulting in formation of $\mathrm{Li}_{2} \mathrm{C}_{6}$ corresponding to a storage capacity of nearly $744 \mathrm{~mA} \mathrm{~h} \mathrm{~g}^{-1}$ that is two times that of graphite [7]. Gerouki et al. [8] calculated the specific capacity of graphene sheets of size $\sim 0.7 \mathrm{~nm}$ as $1488 \mathrm{~mA} \mathrm{~h} \mathrm{~g}^{-1}$ that corresponded to formation of $\mathrm{Li}_{4} \mathrm{C}_{6}$. Therefore, graphene shows potential as a battery anode material because of its large surface area $\left(2600 \mathrm{~m}^{2} \mathrm{~g}^{-1}[9\right.$, $10]$ as well as its high electronic conductivity (sheet resist-

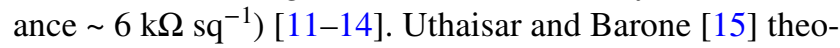
retically investigated $\mathrm{Li}$-ion diffusion in graphene nanoribbons and predicted that lower energy barriers could be found only at a few nanometers from the ribbon-edges leading to faster discharge performance at the edges. Using density functional theory, Pan et al. [9] studied lithium storage in pyrolysis and electron beam irradiation-induced disordered graphene nanosheets (described as having a ripplelike microstructure) and concluded that the observed high capacity of 1013-1054 $\mathrm{mA} \mathrm{h} \mathrm{g}^{-1}$ could be ascribed to the presence of additional reversible storage sites such as edges and other defects. Therefore, increasing the number of edges 
in graphene anodes would theoretically improve the charge/ discharge performance of lithium-ion batteries.

Experimental studies with single layer graphene, produced by exfoliation of bulk graphite [16], showed a specific capacity of only $540 \mathrm{~mA} \mathrm{~h} \mathrm{~g}^{-1}$. Lian et al. [17] prepared graphene sheets with $\sim 4$ layers through thermal exfoliation and observed that the reversible specific capacity in the first cycle could be as high as $1264 \mathrm{~mA} \mathrm{~h} \mathrm{~g}^{-1}$ by charging/discharging at a current density of $0.10 \mathrm{~A} \mathrm{~g}^{-1}$, and $718 \mathrm{~mA} \mathrm{~h} \mathrm{~g}^{-1}$ at a higher current density of 0.50 $\mathrm{A} \mathrm{g}^{-1}$. Wu et al. [18] doped graphene with $\mathrm{B}$ and $\mathrm{N}$ that showed a high reversible capacity of $>1040 \mathrm{~mA} \mathrm{~h} \mathrm{~g}^{-1}$ at a low charge/discharge rate of $0.05 \mathrm{~A} \mathrm{~g}^{-1}$. Moreover, the doped graphene sheets also demonstrated high-rate capability by producing capacities of $\sim 199 \mathrm{~mA} \mathrm{~h} \mathrm{~g}^{-1}$ (N-doped graphene) and $235 \mathrm{~mA} \mathrm{~h} \mathrm{~g}^{-1}$ (B-doped graphene) even at a high rate of $25.00 \mathrm{~A} \mathrm{~g}^{-1}$. Anodes consisting of $\mathrm{MoS}_{2} / \mathrm{SiO}_{2}$ /graphene hybrids (MSGs) were developed by incorporating amorphous $\mathrm{SiO}_{2}$ with $\mathrm{MoS}_{2}$ and graphene nanosheets [19]. MSGs with $\sim 40 \mathrm{wt} \%$ of $\mathrm{SiO}_{2}$ and $\sim 42 \mathrm{wt} \%$ of $\mathrm{MoS}_{2}$ depicted a stable specific capacity of $1060 \mathrm{~mA} \mathrm{~h} \mathrm{~g}^{-1}$ for more than 100 cycles at a current density of $0.1 \mathrm{~A} \mathrm{~g}^{-1}$. Further, capacity of MSG electrodes lowered to $580 \mathrm{~mA} \mathrm{~h} \mathrm{~g}^{-1}$ at a high current density of 8.0 $\mathrm{A} \mathrm{g}^{-1}$. Graphene oxide (GO)-based anodes also showed higher capacity at lower rates. For example, Wu et al. [20] prepared anodes consisting of reduced GO enclosed $\mathrm{Si} /$ porous carbon nanofibers and obtained a high reversible capacity of $1851.3 \mathrm{~mA} \mathrm{~h} \mathrm{~g}^{-1}$ at a low current density of $0.2 \mathrm{~A} \mathrm{~g}^{-1}$ with negligible capacity fading up to the 50th cycle. When a high current density of $4.0 \mathrm{~A} \mathrm{~g}^{-1}$ was used, the capacity was recorded as only $421.5 \mathrm{~mA} \mathrm{~h} \mathrm{~g}^{-1}$. Guzman et al. [21] dispersed Si nanoparticles on reduced GO sheets and the Si/GO composite anode depicted a high discharge capacity $>2000 \mathrm{~mA} \mathrm{~h} \mathrm{~g}^{-1}$ in the first cycle when cycled at a low rate of $0.5 \mathrm{~A} \mathrm{~g}^{-1}$. The capacity decreased to $<500 \mathrm{~mA} \mathrm{~h} \mathrm{~g}^{-1}$ when a high rate of $2.5 \mathrm{~A} \mathrm{~g}^{-1}$ was used. The measured capacities and the rates reported for different types of graphene-based anode materials are summarized in Table 1. In general, a high specific capacity of graphene-based anodes was achieved only at low charge/ discharge rates.

Li-ion batteries depict limited performance at elevated temperatures, and their cycle life is limited due to surface phenomena on both electrodes that increase their impedance upon cycling $[22,23]$. Changes are known to occur both in the electrolyte and the SEI films with the increase in the cycling temperature. Spotnitz et al. [24] performed accelerating rate calorimetry simulations and suggested that the SEI decomposes at temperatures around $70{ }^{\circ} \mathrm{C}$. At still higher temperatures $\left(\sim 110^{\circ} \mathrm{C}\right)$, the components of the SEI layers $\left(\mathrm{LiC}_{\mathrm{x}}\right)$ would react with the electrolyte solvent when carbon-based anodes are used. The electrolyte solvent would decompose only when the cycling temperature exceeds $180{ }^{\circ} \mathrm{C}$ [24]. Smart et al. [25] suggested that the SEI films formed on mesocarbon microbead (MCMB) electrodes were protective at high temperatures and prevents further electrolyte reduction at the electrode surfaces. In another work, Smart et al. [26] proposed that Li-ion cells containing electrolytes with higher proportion of EC displayed lower irreversible capacity loss after being exposed to high temperature compared with cells containing low-EC content electrolytes.

This study aims to explore the possibility to achieve high capacity of graphene nanoflake-based anodes at the same charge/discharge rate by cycling at $50{ }^{\circ} \mathrm{C}$. In-situ Raman spectroscopy was performed simultaneously while conducting cyclic voltammetry (CV) experiments to measure solvent intercalation-induced strains in graphene nanoflakes. The observed improvement in the electrochemical performance of graphene nanoflakes due to cycling at an elevated temperature of $50{ }^{\circ} \mathrm{C}$ was discussed in terms of the morphology of the SEI and solvent co-intercalation induced strain compared to those observed during cycling graphene at room temperature.

Table 1 Cycling rate dependency of specific capacities as reported in the literature

\begin{tabular}{|c|c|c|c|c|c|}
\hline \multirow[t]{2}{*}{ Graphene-based anode material } & \multicolumn{2}{|c|}{$\begin{array}{l}\text { Specific capacity at low } \\
\text { rate }\end{array}$} & \multicolumn{2}{|c|}{ Specific capacity at high rate } & \multirow[t]{2}{*}{ References } \\
\hline & $\begin{array}{l}\text { Capacity } \\
(\mathrm{mA} \mathrm{h} \\
\left.\mathrm{g}^{-1}\right)\end{array}$ & Rate $\left(\mathrm{A} \mathrm{g}^{-1}\right)$ & Capacity $\left(\mathrm{mA} \mathrm{h} \mathrm{g}^{-1}\right)$ & $\overline{\text { Rate }\left(\mathrm{A} \mathrm{g}^{-1}\right)}$ & \\
\hline $\begin{array}{l}\text { Graphene sheets ( } \sim 4 \text { layers) through thermal exfolia- } \\
\text { tion }\end{array}$ & 1264 & 0.10 & 718 & 0.50 & Lian et al. [17] \\
\hline B- and N-doped graphene & $>1040$ & 0.05 & $\begin{array}{l}199 \text { (N-doped graphene) } \\
235 \text { (B-doped graphene) }\end{array}$ & 25.00 & Wu et al. [18] \\
\hline $40 \mathrm{wt} \% \mathrm{SiO}_{2} / 42 \mathrm{wt} \% \mathrm{MoS}_{2} /$ graphene hybrids & 1060 & 0.10 & 580 & 8.00 & Han et al. [19] \\
\hline Reduced GO enclosed Si/porous carbon nanofibers & $\sim 1851$ & 0.20 & $\sim 422$ & 4.00 & Wu et al. [20] \\
\hline $\mathrm{Si} / \mathrm{GO}$ composite & $>2000$ & 0.50 & $<500$ & 2.50 & Guzman et al. [21] \\
\hline
\end{tabular}




\section{Materials and methods}

\section{Description of anode materials and electrochemical experiments}

The graphene nanoflakes used in making the anodes had an average thickness of $<3 \mathrm{~nm}$. The lateral dimensions of the flakes were 2-8 $\mu \mathrm{m}$ (Graphene Laboratories Inc., USA). Raman spectra obtained from the graphene flakes exhibited a G-band at $1580 \mathrm{~cm}^{-1}$ as shown in Fig. 1. The formation of this peak was attributed to the in-plane vibration of the $s p^{2}$-hybridized carbon atoms [27, 28]. A small peak was also observed at $1340 \mathrm{~cm}^{-1}$ (D-band) that was attributed to structural disorder in the graphene flakes $[29,30]$ - the edges and cracks within the flakes may contribute to the disorder. The Raman spectrum of graphene was also characterized by a peak at $2700 \mathrm{~cm}^{-1}$ (2D or G' $[29,31]$ ) that corresponds to the overtone of the D-band [28]. The height of the 2D-band is an indicator of the number of graphene layers [1]. In Fig. 1, the height of the 2D-band was lower than the G-band indicating a multi-layered structure $[32,33]$. The $I_{2 \mathrm{D}} / I_{\mathrm{G}}$ value was measured from many different locations as well and was found to be $0.62 \pm 0.50$ - the ratio varied with the number of graphene layers in different stacks that

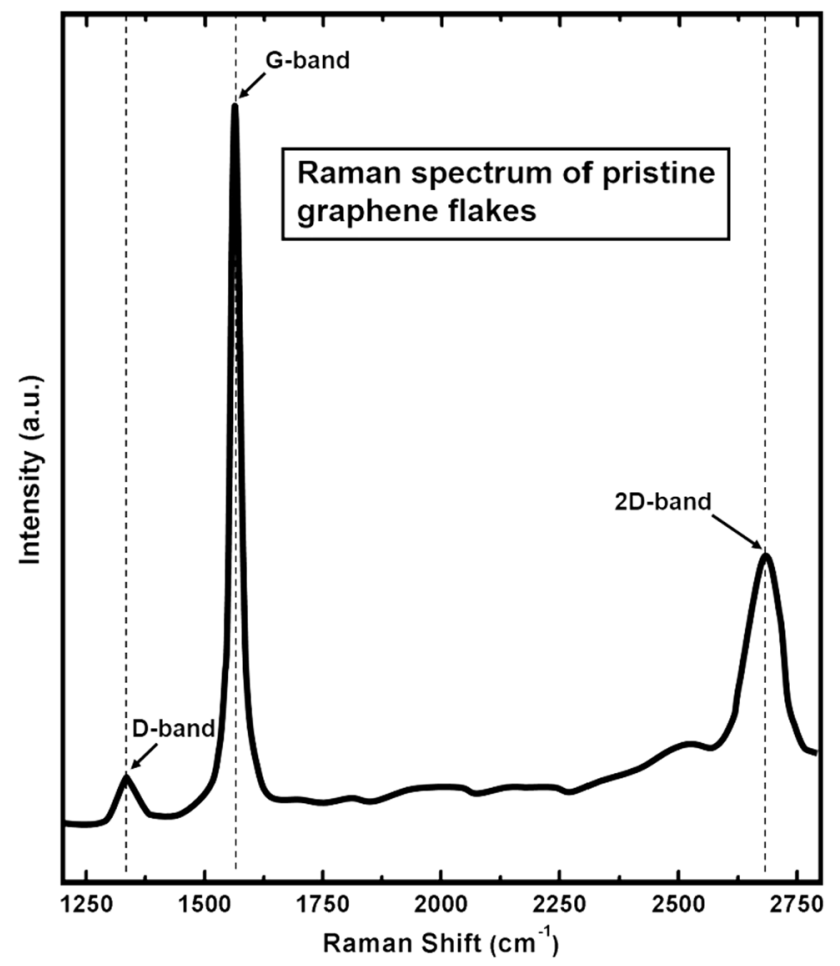

Fig. 1 Typical Raman spectra obtained from pristine graphene nanoflakes prior to cycling scattered the laser (2-3 graphene layers in some locations while 50-60 in others).

The anodes were prepared by mixing ultrasonically 80 $\mathrm{wt} \%$ of graphene flakes with $20 \mathrm{wt} \%$ of polyvinylidene fluoride (PVDF)-binder (MTI Corporation, USA) dissolved in 1-methyl-2-pyrrolidinone (99.5\%). The slurries prepared in this way were coated on the top surfaces of copper current collectors with surface area of $0.2 \mathrm{~cm}^{2}$ and the mass loading was calculated as $15.3 \pm 0.3 \mathrm{mg} \mathrm{cm}^{-2}$. The electrodes were then dried for $12 \mathrm{~h}$ at $105{ }^{\circ} \mathrm{C}$ in an oven and transferred in an Argon glovebox (MBraun LABstar) where $\mathrm{H}_{2} \mathrm{O}$ and $\mathrm{O}_{2}$ levels were maintained below $1 \mathrm{ppm}$. The electrodes were then mounted in an electrochemical cell inside the glovebox. The electrochemical cell was constructed from polytetrafluoroethylene (PTFE), and had a quartz (optical) glass window on its top surface for monitoring of real time structural changes in the graphene nanoflakes by a Raman objective during the tests. A $99.99 \%$ pure $\mathrm{Li}$ wire with a resistivity of $9.446 \mu \Omega$-cm (at $20{ }^{\circ} \mathrm{C}$ ) was used as both the counter electrode and the reference electrode. The electrolyte solution was prepared using $1 \mathrm{M} \mathrm{LiClO}_{4}(99 \%)$ in a 1:1 (by vol.) mixture of ethylene carbonate (EC, 99\%) and 1,2-dimethoxy ethane (DME, 99\%).

Galvanostatic experiments were conducted by initially applying a voltage of $3.00 \mathrm{~V}$ and reducing it to $0.02 \mathrm{~V}$ (vs. $\mathrm{Li} / \mathrm{Li}^{+}$) using a Potentiostat/Galvanostat system (Solartron Modulab with a data acquisition rate of up to $1.0 \mathrm{MS} \mathrm{s}^{-1}$ ). The charge/discharge rate used was $0.04 \mathrm{~A} \mathrm{~g}^{-1}$ (current density $=0.60 \mathrm{~mA} \mathrm{~cm}^{-2}$, which was calculated considering the entire electrode surface area, $19.62 \mathrm{~mm}^{2}$ ). CV experiments were conducted between $3.00 \mathrm{~V}$ and $0.02 \mathrm{~V}$ vs. $\mathrm{Li} / \mathrm{Li}^{+}$at a constant voltage scan rate of $2.00 \mathrm{mV} \mathrm{s}^{-1}$ for measuring the lithiation/delithiation-induced strain in graphene. Both galvanostatic and $\mathrm{CV}$ experiments were performed at a temperature of $50{ }^{\circ} \mathrm{C}$. The temperature of the cell was controlled using a heater located at the base of the cell and the temperature was maintained within $\pm 1{ }^{\circ} \mathrm{C}$ of the test temperature.

\section{In-situ Raman spectroscopy and SEM characterization}

A 50× objective of a Raman spectrometer (Horiba), equipped with a CCD detector, was used to determine in situ structural changes in graphene nanoflakes during the galvanostatic experiments, as well as to measure the solvent intercalation-induced strain during $\mathrm{CV}$ experiments. Raman measurements were performed while the electrodes were installed inside the closed cell. A schematic representation of the experimental setup is shown in Fig. 2. A 50 $\mathrm{mW}$ Nd-YAG solid-state laser diode emitting a continuous wave laser at the 532-nm excitation line was used to obtain Raman spectra. 


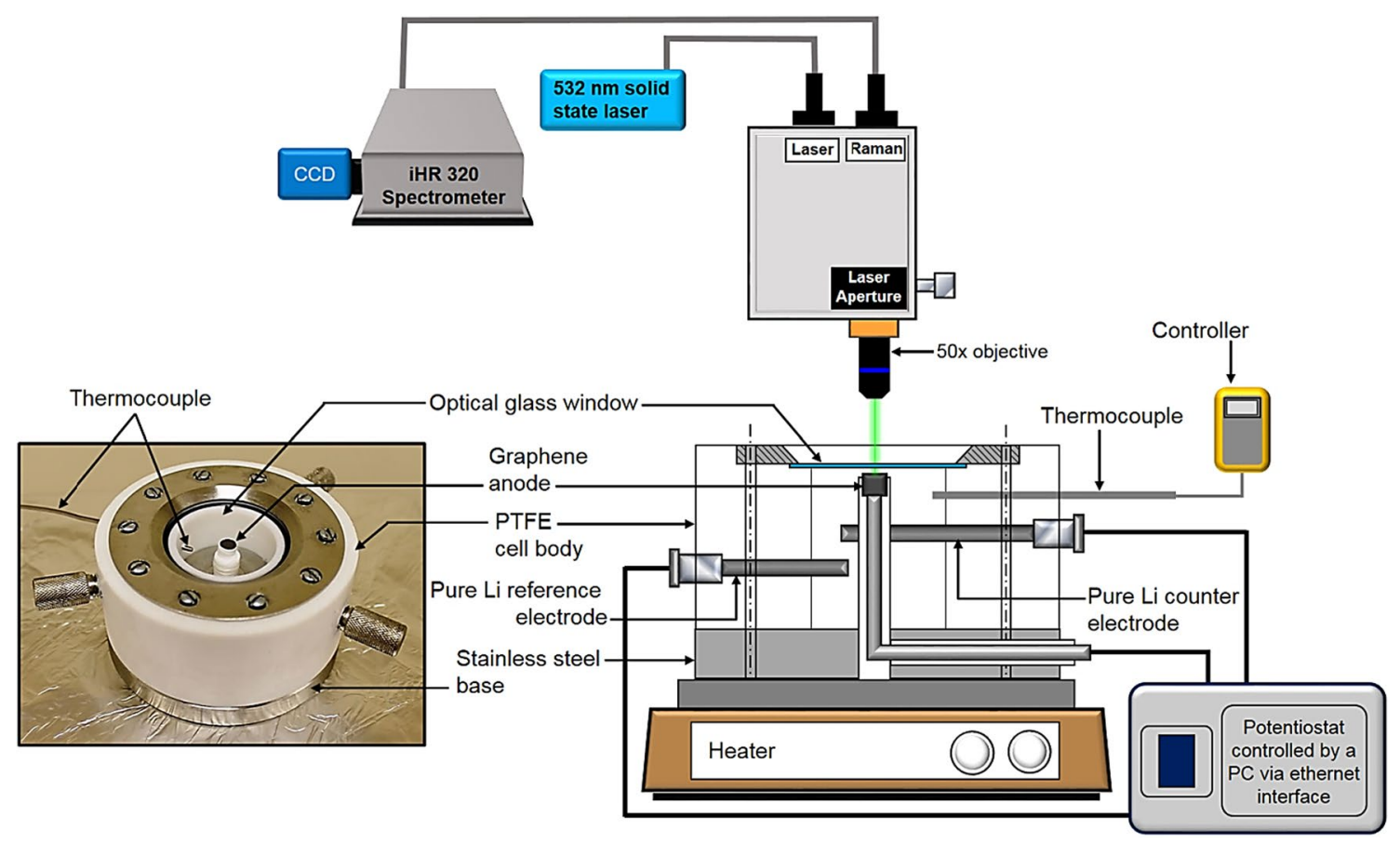

Fig. 2 Schematic representation of the experimental setup used for in situ Raman spectroscopy of surface changes in graphene nanoflake-based anodes cycled in an electrochemical cell with glass window at elevated temperatures

At the end of each experiment, the electrodes consisting of graphene nanoflakes were carefully removed from the electrochemical cell, mounted on stainless steel stubs in ambient air, and transferred to the SEM chamber. An FEI Quanta 200 FEG scanning electron microscope (SEM) and a FEI Magellan 400 SEM with sub-nanometer resolution operated at $1-5 \mathrm{kV}$ was used to study the surface morphologies of the electrodes before and after the electrochemical experiments performed at 25 and $50^{\circ} \mathrm{C}$.

\section{Results and discussion}

\section{Charge/discharge profiles during galvanostatic cycling of graphene nanoflakes}

An optical image of the graphene electrode obtained at the beginning of the galvanostatic experiments at $3.00 \mathrm{~V}$ is shown in Fig. 3a. The laser spot can be seen on the electrode surface. Similar to graphite, graphene was observed to undergo colour change [34] upon a decrease in the voltage, i.e., during the lithium intercalation stage of the galvanostatic experiments, from black in the pristine state to a reddish-yellow intermediate compound at $0.03 \mathrm{~V}$ (Fig. 3b) and golden yellow in the fully lithiated electrode at $0.02 \mathrm{~V}$ (Fig. 3c). The color is thought to be indicative of the electrode's state-of-charge [34].
The galvanostatic charge/discharge profiles of cycled graphene nanoflakes were recorded for the first and second cycles as shown in Fig. 4a. A prominent plateau was observed at $0.75 \mathrm{~V}$ during lithiation of graphene in the first cycle. The presence of this plateau can be attributed to the reduction of the solvent species of the electrolyte and formation of an SEI layer on the surfaces of graphene [35, 36]. The electrolyte has an oxidation potential around $4.70 \mathrm{~V}$ vs. $\mathrm{Li} /$ $\mathrm{Li}^{+}$and reduction potential close to $0.90 \mathrm{~V}$ vs. $\mathrm{Li} / \mathrm{Li}^{+}$that defines the electrochemical stability window of the electrolyte [37, 38]. The electrolyte decomposition and subsequent SEI formation on the electrode surface takes place at potentials close to $0.80 \mathrm{~V}$ vs. $\mathrm{Li}^{2} \mathrm{Li}^{+}[35,36]$. The electrolyte decomposition potential could vary depending on the current density or voltage scan rate used during the electrochemical experiments [6]. In this case, the reduction of electrolyte occurred at $0.75 \mathrm{~V}$. For experiments conducted at $50{ }^{\circ} \mathrm{C}$, a plateau was observed at a voltage around $0.85 \mathrm{~V}$, which was higher than the voltage at which the plateau formed at $25^{\circ} \mathrm{C}$ $(0.75 \mathrm{~V})$. Specific capacity was calculated by considering the mass loading of the graphene flakes. At $50^{\circ} \mathrm{C}$, the first cycle specific capacity was as high as $856 \mathrm{~mA} \mathrm{~h} \mathrm{~g}^{-1}$ compared to $636 \mathrm{~mA} \mathrm{~h} \mathrm{~g}^{-1}$ observed at $25^{\circ} \mathrm{C}$. The enhanced charge and discharge behaviour of graphene at $50{ }^{\circ} \mathrm{C}$ may be due to increased and time-dependent lithium insertion within the defects like edges, dislocations, cracks [39], nano-cavities 
(a)

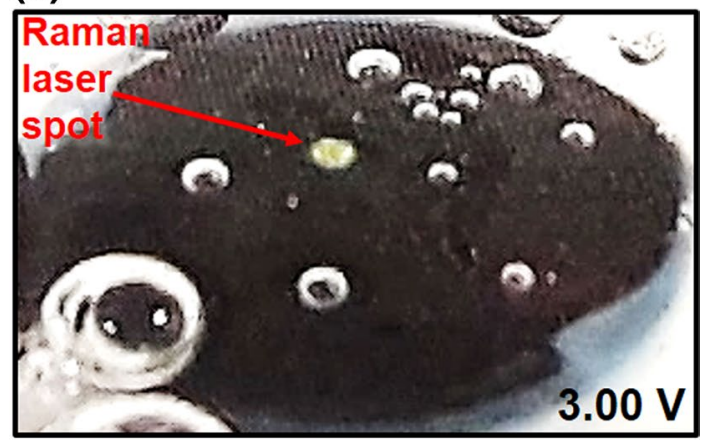

(b)

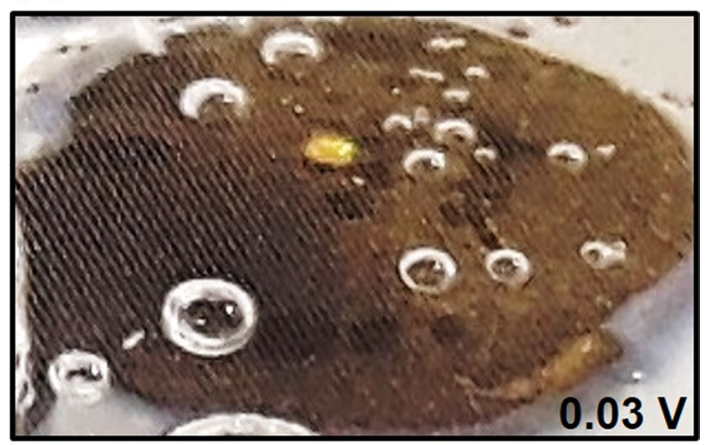

(c)

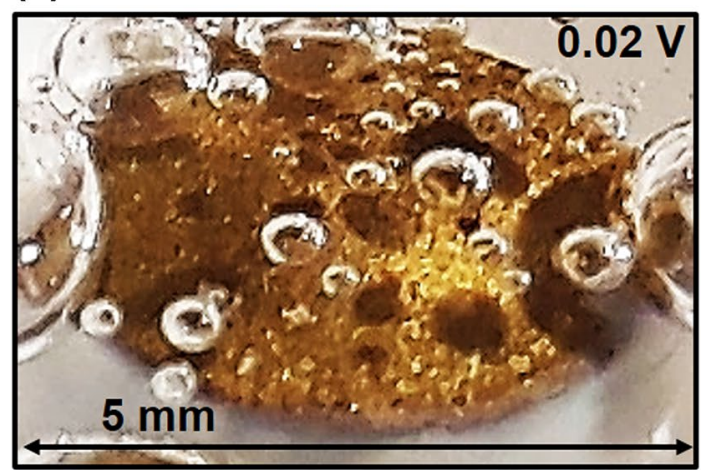

Fig. 3 In-situ optical images of the graphene nanoflake-based anodes depicting the following colours: a black at $3.00 \mathrm{~V}$ (no lithium); b reddish-yellow at $0.03 \mathrm{~V}$ (partially lithiated), and $\mathbf{c}$ golden yellow at $0.02 \mathrm{~V}$ (fully lithiated)

between the graphene flakes and improved adsorption of lithium on each side of the flakes $[40,41]$.

At the end of the second cycle of the test performed at $25^{\circ} \mathrm{C}$, the capacity was calculated as $294 \mathrm{~mA} \mathrm{~h} \mathrm{~g}^{-1}$ that amounted to a capacity loss of 54\%. This large irreversible capacity loss can be attributed to the formation of SEI at the surfaces and edges of the graphene flakes [40, 41]. In contrast, the capacity loss was measured as $48 \%$ that amounted to a capacity of $445 \mathrm{~mA} \mathrm{~h} \mathrm{~g}^{-1}$ at $50{ }^{\circ} \mathrm{C}$ in the second cycle. Therefore, by cycling at an elevated temperature, an improvement in the electrochemical performance of graphene flakes was achieved even at the same current density as opposed to previous observations (see Table 1) that depicted capacity increase only at low rates. The lower capacity observed in the second cycle at $25^{\circ} \mathrm{C}$ could be related to the morphology of SEI formed that will be discussed in the following section.

The change in the specific capacity of graphene flakes with the number of cycles were calculated for tests conducted at 25 and $50{ }^{\circ} \mathrm{C}$ and the results are plotted in Fig. $4 \mathrm{~b}$. During the test performed at $25^{\circ} \mathrm{C}$, the capacity dropped from 636 to $294 \mathrm{~mA} \mathrm{~h} \mathrm{~g}^{-1}$ and after the second cycle, the capacity declined gradually. At the end of the 50th cycle, the capacity obtained was as low as $45 \mathrm{~mA} \mathrm{~h} \mathrm{~g}^{-1}$. However, for experiments performed at $50{ }^{\circ} \mathrm{C}$, it was observed that the capacity was always higher than that obtained at $25^{\circ} \mathrm{C}$. The capacity measured at $50{ }^{\circ} \mathrm{C}$ in the 50th cycle was $134 \mathrm{~mA} \mathrm{~h}$ $\mathrm{g}^{-1}$.

In summary, the specific capacity of graphene nanoflakebased anodes at $50{ }^{\circ} \mathrm{C}$ was higher than that at $25{ }^{\circ} \mathrm{C}$. The cyclic performance of graphene would depend on the morphologies of the SEI formed on graphene at these two temperatures, as discussed in the next section.

\section{SEM observations of surfaces of cycled graphene nanoflakes}

SEM observations were conducted to investigate the electrochemical cycling induced morphological changes that occurred in the graphene anodes. A secondary electron (SE)-SEM image of an anode consisting of graphene nanoflakes prior to cycling is shown in Fig. 5a. Before cycling, the graphene flakes could be recognized by their dark grey contrast. After 50 galvanostatic cycles, it was observed that the surfaces of the graphene flakes (in completely discharged state) were covered with SEI deposits identified by their brighter contrast, as can be seen in Fig. 5b. The SEI formed at $25^{\circ} \mathrm{C}$ was discontinuous and in the form of overlapping deposits or layers, each of size ranging between 50 and $100 \mathrm{~nm}$. In this case, the SEI consisted of large pores and cavities (size ranging from $200 \mathrm{~nm}$ to $1 \mu \mathrm{m}$ ) in between and possibly regions of graphene flake surfaces exposed to further electrochemical reduction [6] that could be responsible for the lower capacity at $25^{\circ} \mathrm{C}$ as seen in Fig. 4 a. The morphology of the graphene surfaces cycled at $50{ }^{\circ} \mathrm{C}$ using the same current density showed that the graphene surfaces were completely covered by SEI deposits. Examination of the electrode surfaces showed that the deposits covered the surfaces of the graphene flakes more uniformly. The deposits had a tubular morphology with an intertwined structure (Fig. 5c). Therefore, it can be suggested that a more uniform SEI formed at $50{ }^{\circ} \mathrm{C}$ was more stable. It is possible that a stable and uniform SEI assisted in efficient Li-ion diffusion that, in turn, provided the higher capacity

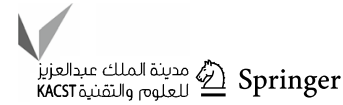


Fig. 4 a Charge/discharge profiles obtained during cycling of graphene nanoflake-based anodes at 25 and $50{ }^{\circ} \mathrm{C}$ and $\mathbf{b}$ specific capacities of graphene flakes at 25 and $50{ }^{\circ} \mathrm{C}$ using a charge/discharge rate of 0.04 $\mathrm{Ag}^{-1}$

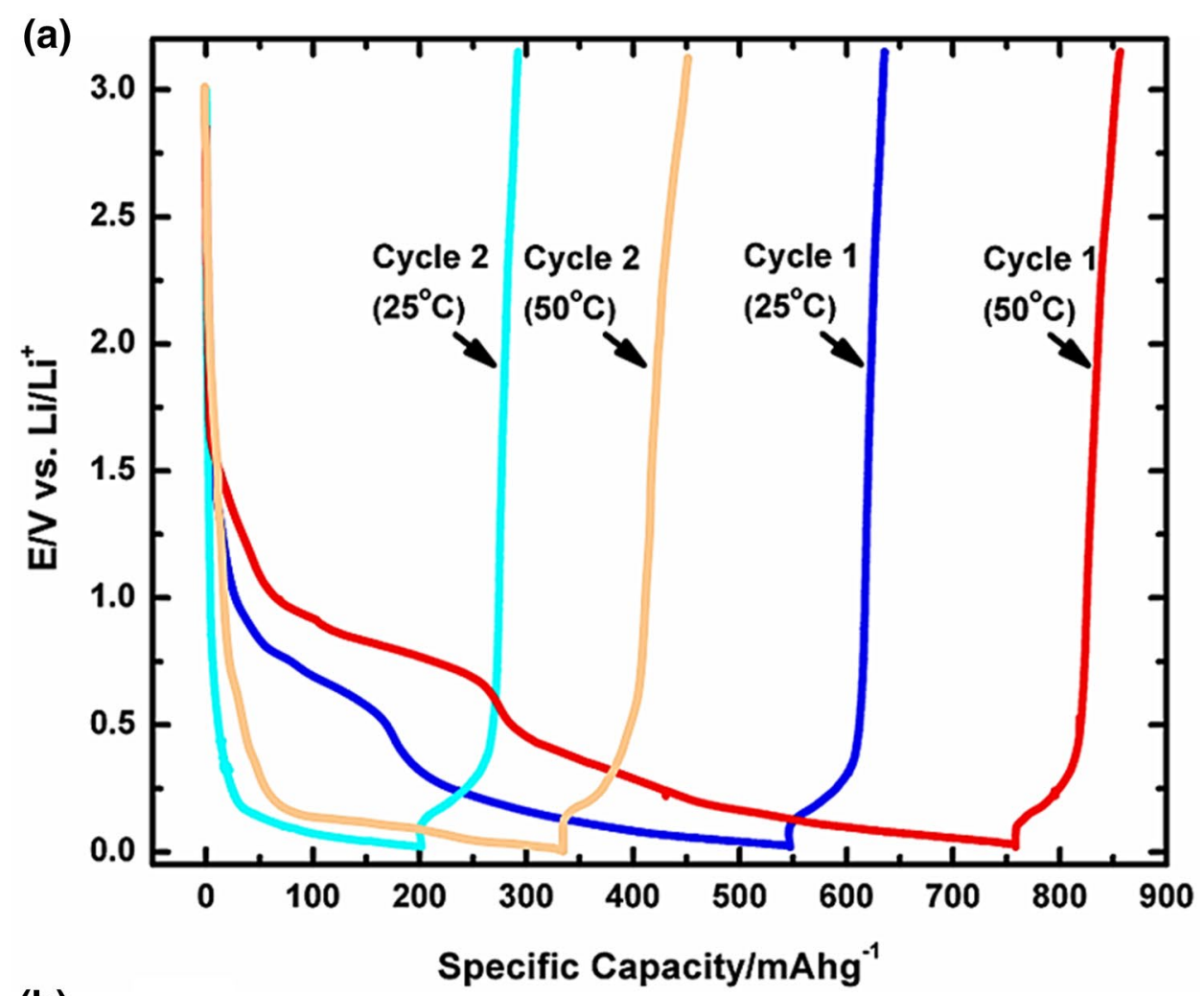

(b)

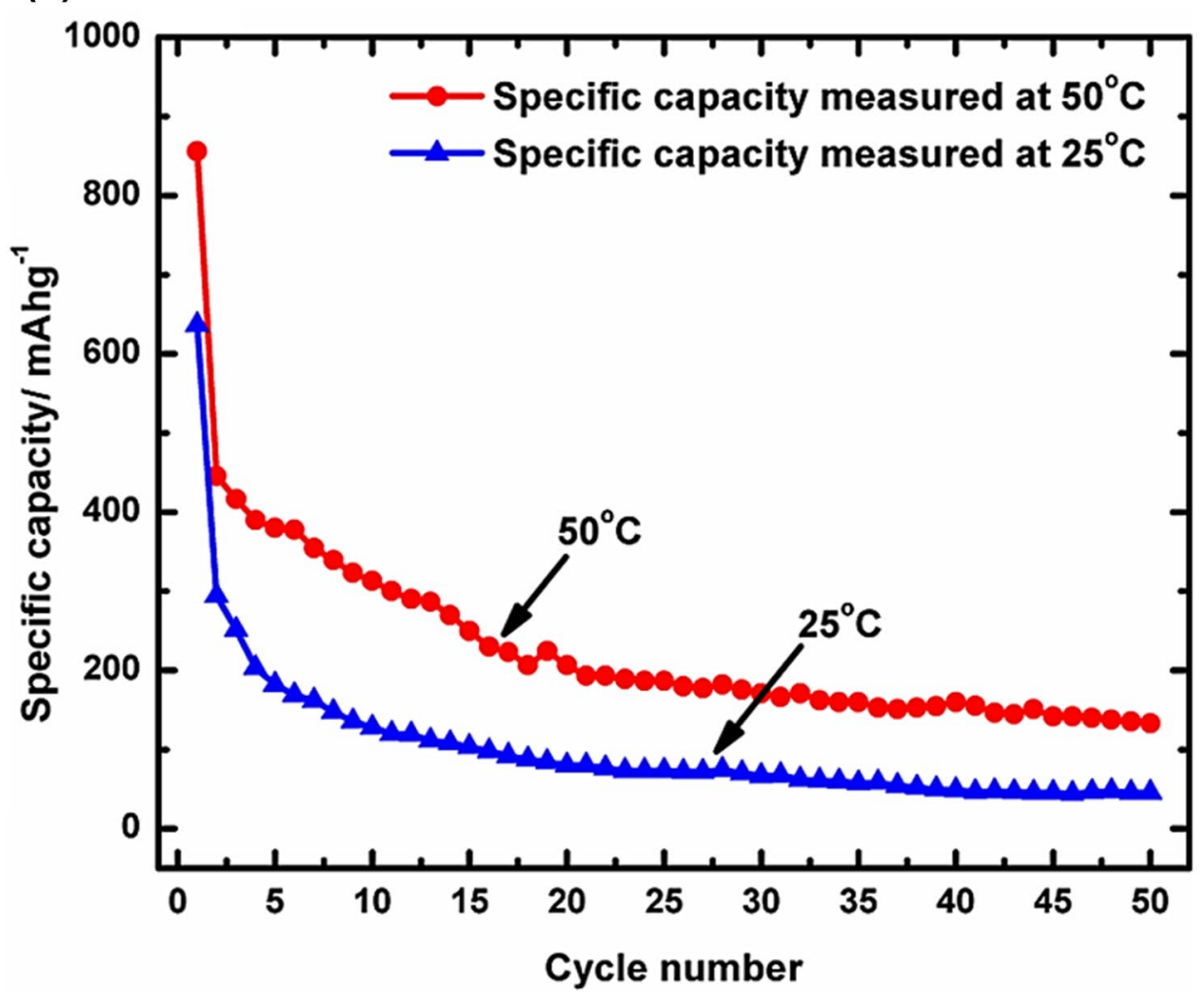

to graphene [42]. Previously it was observed that the SEI films formed on graphite-based anodes, after cycling in EC-based electrolytes, consisted of crystalline domains enclosed in an amorphous matrix [6]. The crystalline domains in the SEI primarily consisted of $\mathrm{Li}_{2} \mathrm{CO}_{3}$ that were thought to enhance Li-ion diffusivity across the 
(a)

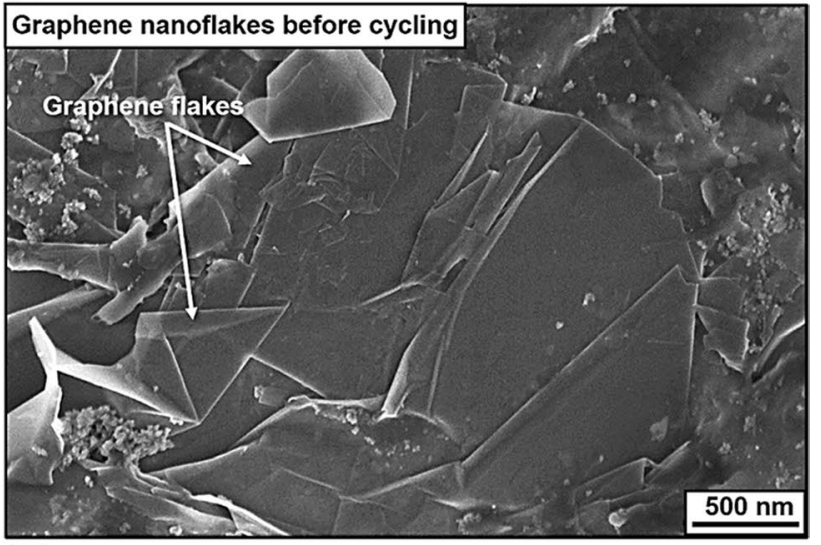

(b)

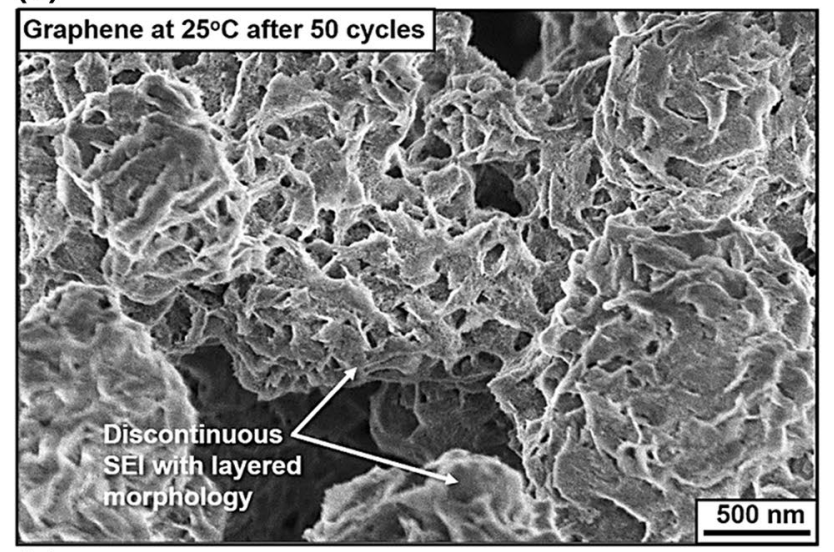

(c)

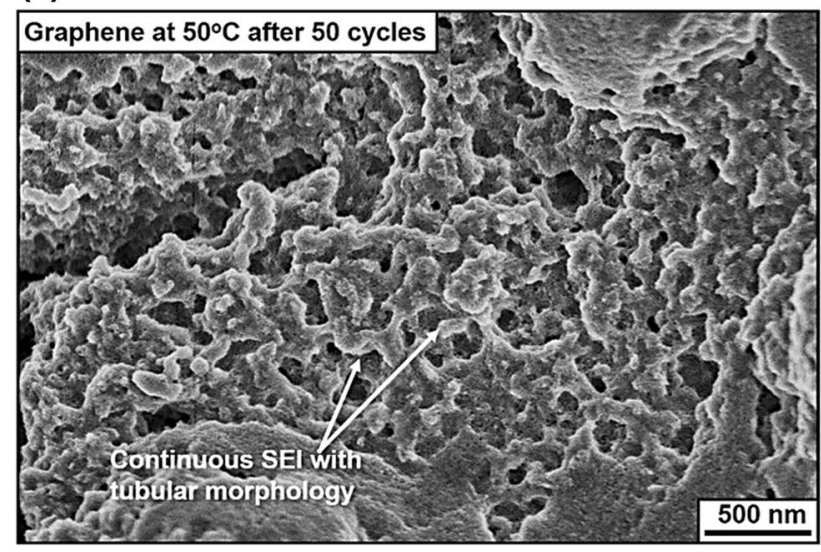

Fig. 5 SE-SEM images obtained from graphene nanoflake-based anodes a before cycling and after 50 cycles at b $25^{\circ} \mathrm{C}$ and c $50{ }^{\circ} \mathrm{C}$

electrode/electrolyte interface $[6,43]$. It is to be noted that a fraction of the SEI could be lost when exposed to the high voltage electron beam inside the vacuum chamber of the SEM. However, care was taken such that the areas on the electrode surfaces that were exposed to the beam for longer durations were not considered for analyses.

\section{Measurement of intercalation-induced strain and disorder in graphene nanoflakes using Raman spectroscopy}

Raman spectroscopy was performed to record changes in the surface characteristics of the graphene flakes as a function of the $\mathrm{Li}$-ion cell temperature $\left(25\right.$ and $\left.50^{\circ} \mathrm{C}\right)$ and the results are shown in Fig. 6. The Raman spectrum of anodes containing graphene flakes before cycling indicated that the intensity of the D-band at $1340 \mathrm{~cm}^{-1}$ increased slightly compared to that observed in as-received condition in Fig. 1. The increased intensity was attributed to an increase in the structural disorder in the graphene flakes by means of ultrasonication during the electrode preparation. The intensity ratio of the G-band $\left(I_{\mathrm{G}}\right)$ to the D-band $\left(I_{\mathrm{D}}\right), I_{\mathrm{D}} / I_{\mathrm{G}}$ was 0.40 before cycling. At the end of 50 galvanostatic cycles at $25{ }^{\circ} \mathrm{C}$, the ratio of $I_{\mathrm{D}} / I_{\mathrm{G}}$ increased to 1.06 as the intensity of the D-band increased. The increase in the intensity of the D-band was due to increase in disorder by the formation of new defects possibly as a result of creation of new edges during fracture of the graphene flakes caused by cycling. In addition, binding of lithium to the newly formed edges and defects would also increase the intensity of the D-band. Figure 6 also shows the Raman spectrum obtained from the graphene surfaces subjected to 50 galvanostatic cycles at $50{ }^{\circ} \mathrm{C}$. The D-band had a high intensity and the $I_{\mathrm{D}} / I_{\mathrm{G}}(=1.02)$ calculated in this case was comparable to that obtained during cycling at $25^{\circ} \mathrm{C}$. In addition, the ratio of $I_{\mathrm{G}}$ to the intensity of the 2D-band $\left(I_{2 \mathrm{D}}\right), I_{2 \mathrm{D}} / I_{\mathrm{G}}$, increased from 0.60 before cycling, to 0.80 after cycling at $25{ }^{\circ} \mathrm{C}$, and to 0.79 at $50{ }^{\circ} \mathrm{C}$. The increase in the $I_{2 \mathrm{D}} / I_{\mathrm{G}}$ ratios could be also attributed to generation of cyclinginduced defects in the graphene flakes. Although the amount of disorder induced during cycling was almost the same in both cases, it should be noted that the capacity obtained at $50{ }^{\circ} \mathrm{C}\left(856 \mathrm{~mA} \mathrm{~h} \mathrm{~g}^{-1}\right)$ was $35 \%$ higher than that obtained at $25^{\circ} \mathrm{C}$ (Fig. 4a) possibly due to formation of a stable SEI at that temperature as shown in Fig. $5 \mathrm{c}$.

The process of lithiation would induce strains in the electrode materials' lattices. In order to determine the variations in the strain generated during voltage cycling, in situ Raman spectroscopy was performed simultaneously with the CV experiments conducted between $3.00 \mathrm{~V} \rightarrow 0.02 \mathrm{~V} \rightarrow 3.00 \mathrm{~V}$ vs. Li/ $\mathrm{Li}^{+}$at a scan rate of $2.00 \mathrm{mV} \mathrm{s}^{-1}$. The cyclic voltammograms obtained during cycling at 25 and $50{ }^{\circ} \mathrm{C}$ are shown in Fig. 7 . The $\mathrm{CV}$ curve obtained during cycling of graphene flakes at $25^{\circ} \mathrm{C}$ showed a cathodic reduction voltage peak at $0.75 \mathrm{~V}$ and for the curve obtained at $50{ }^{\circ} \mathrm{C}$, the peak appeared at $0.85 \mathrm{~V}$. The occurrence of the voltage peaks at $0.75 \mathrm{~V}\left(25^{\circ} \mathrm{C}\right)$ and $0.85 \mathrm{~V}\left(50^{\circ} \mathrm{C}\right)$ were in agreement with the voltage of the plateaus obtained during galvanostatic cycling of the graphene

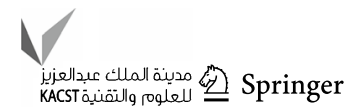


Fig. 6 Raman spectra obtained from graphene nanoflake-based anodes before cycling and after 50 cycles at 25 and $50{ }^{\circ} \mathrm{C}$

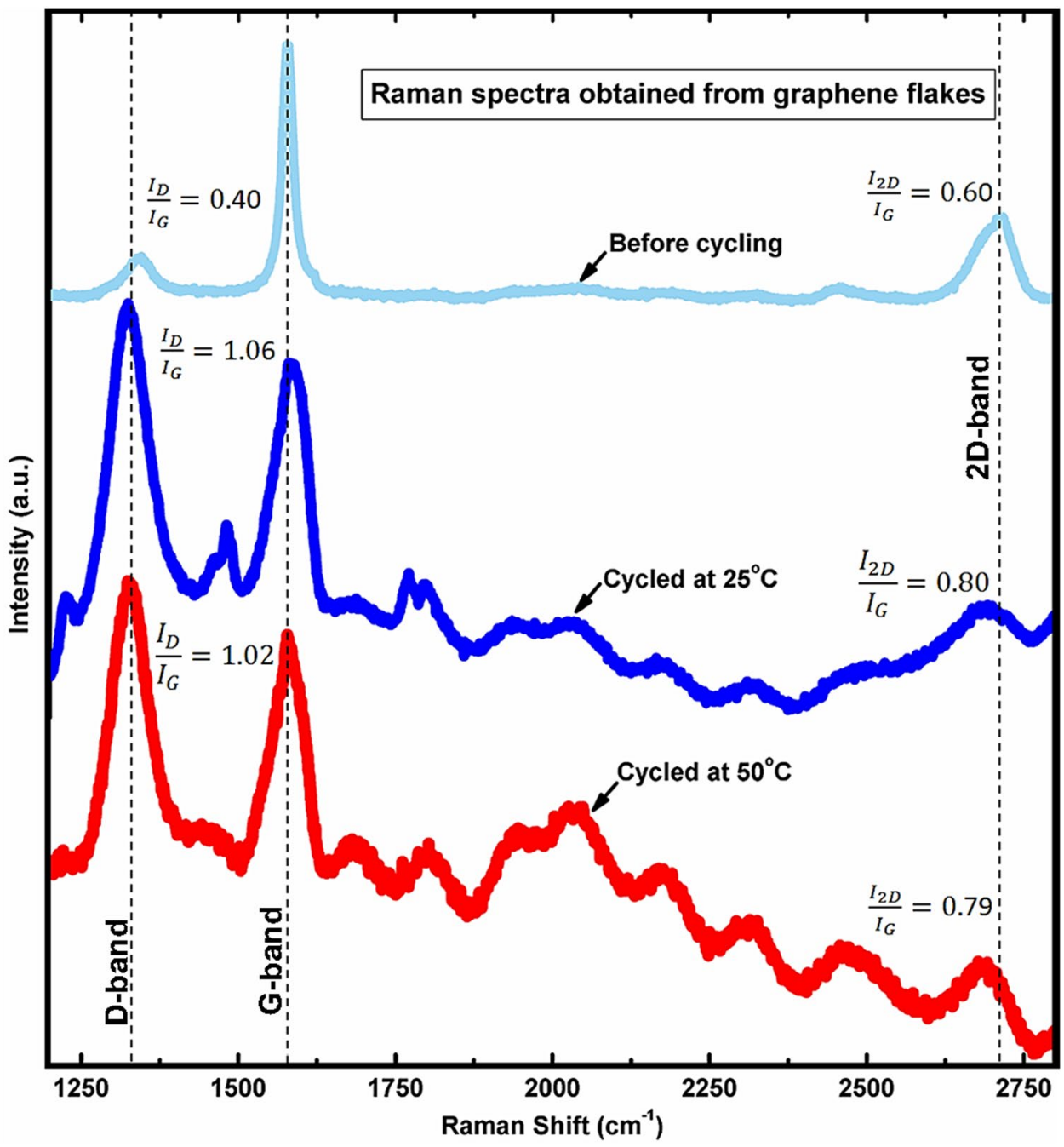

electrodes (Fig. 4a). Formation of these peaks could be attributed to the formation of an SEI layer on the surfaces of the graphene flakes as a result of reduction of the electrolyte [44].

A series of in situ Raman spectra obtained during these CV experiments at 3.00, 0.20 and $0.02 \mathrm{~V}$ showed that the G-band of graphene shifted from $1580 \mathrm{~cm}^{-1}$ (at $3.00 \mathrm{~V}$ ) to higher frequency shifts with the decrease in the voltage from 3.00 V (Fig. 8). For example, the G-band shifted from $1580 \mathrm{~cm}^{-1}$ at $3.00 \mathrm{~V}$ to $1597 \mathrm{~cm}^{-1}$ at $0.02 \mathrm{~V}$ for the graphene flakes cycled at $25^{\circ} \mathrm{C}$, as seen in Fig. 8a. The G-band shifted to only $1583 \mathrm{~cm}^{-1}$ when the voltage was decreased to $0.02 \mathrm{~V}$ during cycling of graphene flakes at $50{ }^{\circ} \mathrm{C}$ (Fig. 8b). The frequency shift of the G-band can be related to the uniaxial strain and the shear strain — but the latter could be ignored due to its minor contribution [45]. The relation between the Raman frequency and the strain could be expressed as [45, 46]:

$\frac{\Delta \omega}{\omega_{o}}=\gamma\left(\varepsilon_{x x}+\varepsilon_{y y}\right)$

where $\omega_{o}$ is the G-band frequency; $\Delta \omega$ is the shift in the frequency; $\gamma=1.80$ is the Grüneisen parameter for graphene
$[47,48] ;_{x x}$ is the uniaxial strain, and ${ }_{y y} \approx-0.2_{x x}$ is the relative strain in the perpendicular direction according to the Poisson's ratio of graphene $(=0.19$ [49]). From these values, the maximum ${ }_{x x}$ for graphene nanoflakes cycled at $25^{\circ} \mathrm{C}$ was calculated as $7.5 \times 10^{-3}$. During the reverse sweep, the G-band shifted back to $1580 \mathrm{~cm}^{-1}$ when the voltage was increased to $3.00 \mathrm{~V}$. The shift in the location of the G-band was previously discussed in terms of the strain increase in the multilayered graphene $[50,51]$. It could be attributed to intercalation of solvent molecules [43]. The changes in the uniaxial strain are plotted as a function of the time and voltage in Fig. 8c. A smaller shift in the location of the G-band was observed in case of graphene cycled at $50{ }^{\circ} \mathrm{C}$, compared to that observed in case of graphene cycled at $25^{\circ} \mathrm{C}$ $(0.75 \pm 0.02 \%)$. This could be attributed to a decrease in the strain to $0.12 \pm 0.03 \%$. Using in situ Raman spectroscopy, the cycling-induced strain in the graphite lattice was estimated as $0.41 \pm 0.01 \%$, which was accompanied by surface degradation of graphite electrodes [43]. Thus, it can be suggested that graphene could accommodate a high strain due 
Fig. 7 Cyclic voltammograms obtained from graphene nanoflake-based anodes cycled at 25 and $50{ }^{\circ} \mathrm{C}$ using a voltage scan rate of $2.00 \mathrm{mV} \mathrm{s}^{-1}$

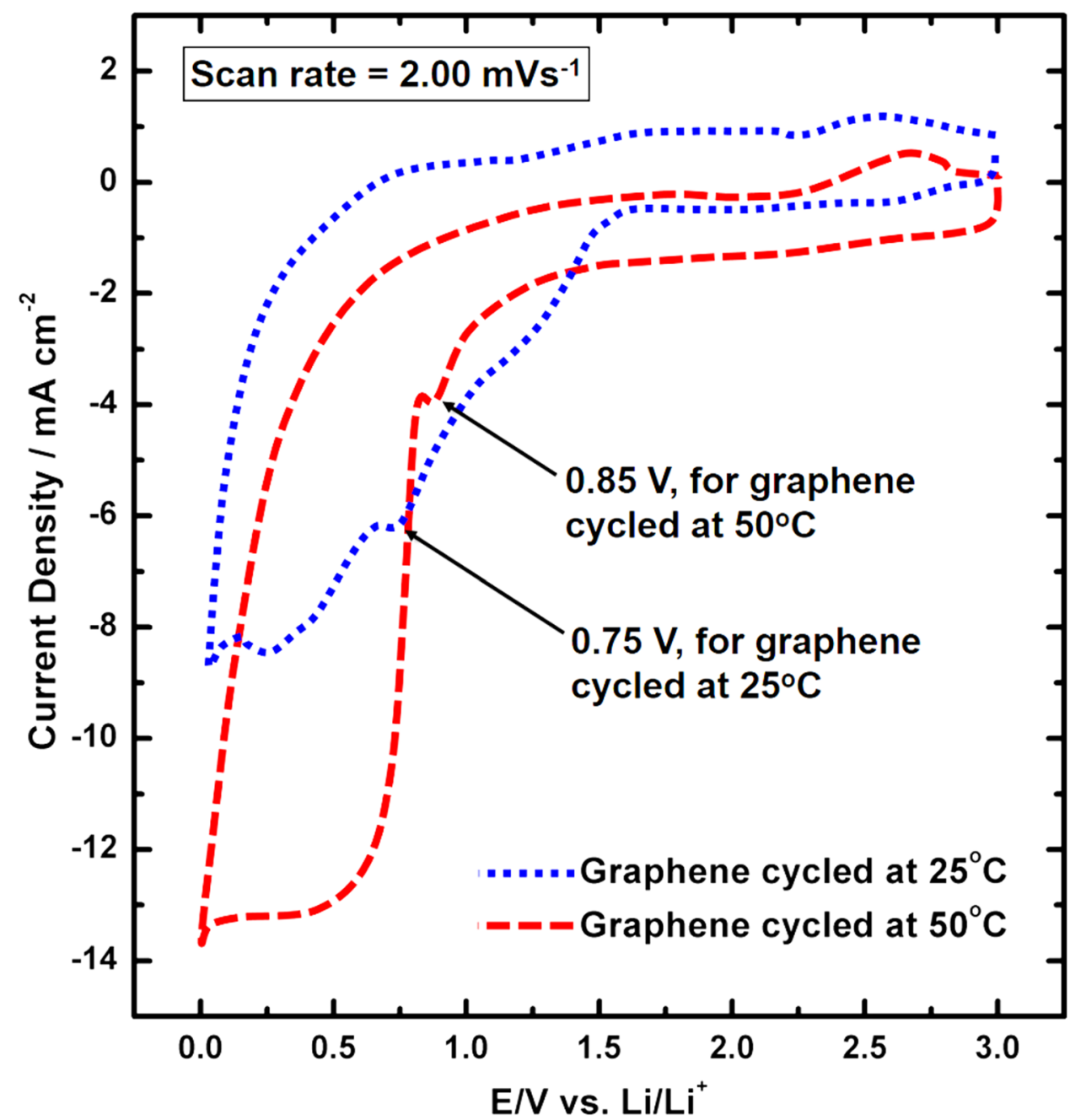

to lithiation and solvent co-intercalation at $25^{\circ} \mathrm{C}$, yet, the strain in graphene nanoflakes could be reduced if the Li-ion cell is cycled at an elevated temperature of $50{ }^{\circ} \mathrm{C}$. This will also yield a $35 \%$ higher specific capacity in the first cycle as described earlier. Although the mechanisms of lithium storage in graphene should be further clarified, a possible reason for the enhanced capacity of graphene at elevated temperatures could be due to the formation of additional sites in the graphene nanoflakes for accommodation of Li-ions [16] and the electrochemical capacity of graphene would depend on the defect density as the defects act as Li-ion storage sites [39-41]. The improved capacity would also depend on the composition of the SEI films formed on the anode surfaces [25, 26, 52]. For example, thermal pre-treatment of Li-ion cells containing graphite anodes at $60^{\circ} \mathrm{C}$ [42] caused

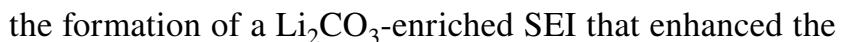
capacity by $28 \%$ compared to that at $25{ }^{\circ} \mathrm{C}$. An SEI enriched with $\mathrm{Li}_{2} \mathrm{CO}_{3}$ is known to provide facile diffusion paths for Li-ions across the SEI [53].

In summary, the results suggested that the capacity of graphene flakes would further increase if graphene is pre-cycled at elevated temperatures that would cause formation of a more uniform and stable SEI possibly due to the faster Li-ion diffusion kinetics. An SEI generated in this way is expected to reduce solvent co-intercalation and provide a higher specific capacity even at the same charging current.

\section{Summary and conclusions}

Li-ion cell anodes fabricated from graphene nanoflakes were subjected to galvanostatic cycling at temperatures of 25 and $50{ }^{\circ} \mathrm{C}$. In-situ Raman spectroscopy was used to investigate the cycling-induced strain generation in the graphene nanoflakes. High-resolution SEM images were used to study the morphologies of the SEI formed on graphene. The main conclusions arising from these investigations are as follows:

1. The specific capacity of graphene nanoflake-based anodes increased by $35 \%$ in the first cycle-from $636 \mathrm{~mA} \mathrm{~h} \mathrm{~g}^{-1}$ at $25^{\circ} \mathrm{C}$, to $856 \mathrm{~mA} \mathrm{~h} \mathrm{~g}^{-1}$ at $50{ }^{\circ} \mathrm{C}$, at the same rate of $0.04 \mathrm{~A} \mathrm{~g}^{-1}$. 
Fig. 8 In-situ Raman spectra obtained from graphene nanoflake-based anodes cycled at $\mathbf{a} 25^{\circ} \mathrm{C}$ and $\mathbf{b}$ $50{ }^{\circ} \mathrm{C}$, while scanning from $3.00 \rightarrow 0.02 \rightarrow 3.00 \mathrm{~V}$ at a scan rate of $2.00 \mathrm{mV} \mathrm{s}^{-1}$. c Plot showing changes in the uniaxial strain measured from the shift in the Raman G-band observed in $\mathbf{a}, \mathbf{b}$ (a)

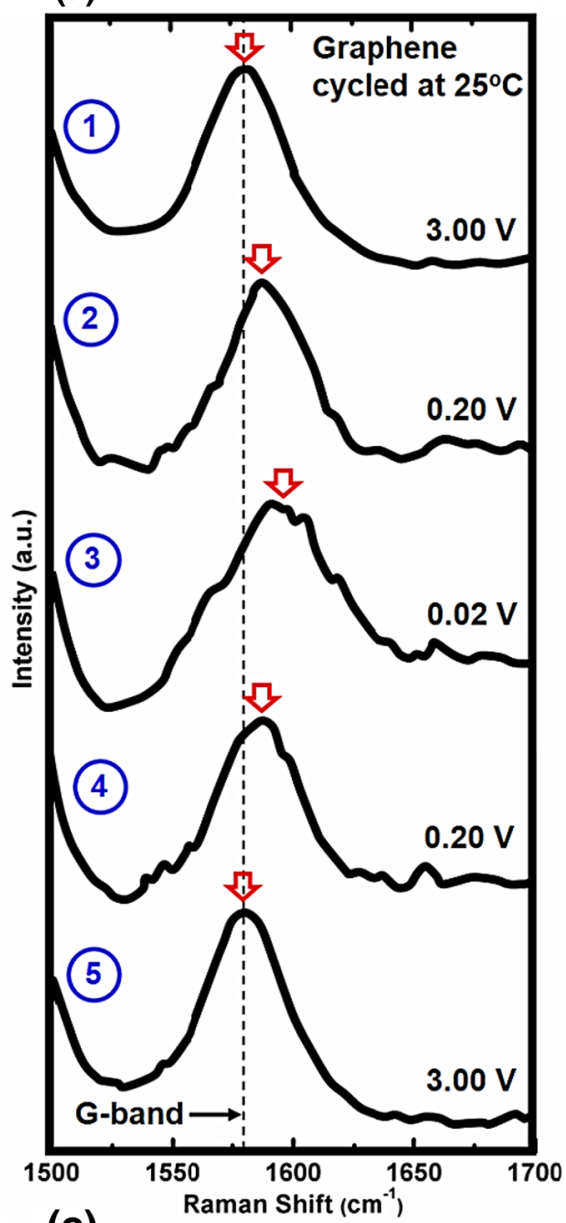

(b)

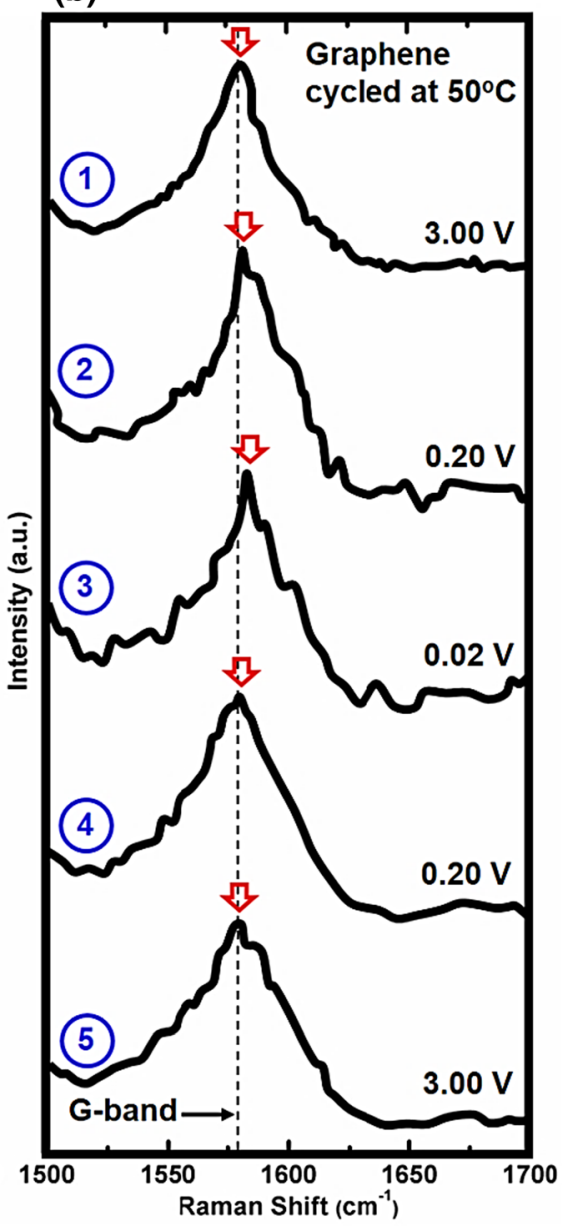

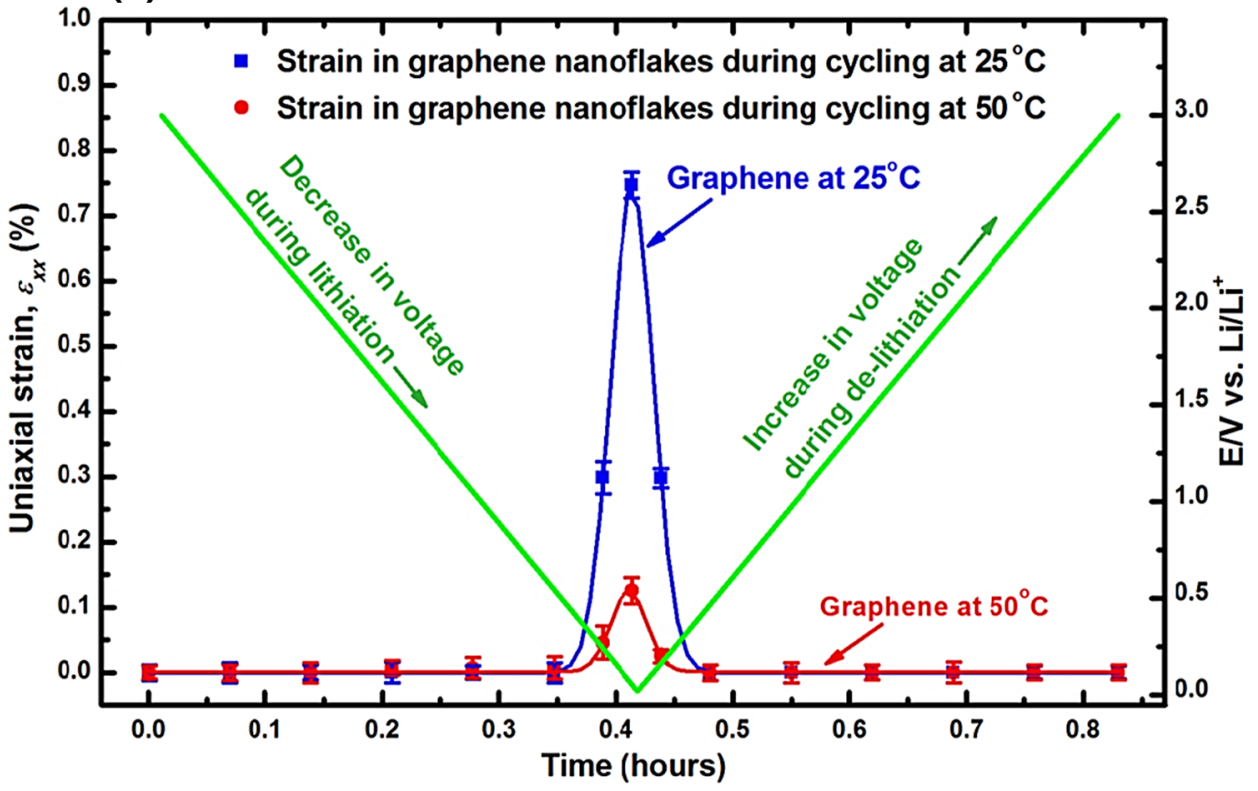

2. The amount of disorder $\left(I_{\mathrm{D}} / I_{\mathrm{G}}=1.02-1.06\right)$ induced during cycling was almost the same at both temperatures. The capacity enhancement that occurred at $50{ }^{\circ} \mathrm{C}$ was

likely to be prompted by the formation of a stable and uniform SEI at that temperature. 
3. The SEI formed at $50{ }^{\circ} \mathrm{C}$ reduced solvent co-intercalation induced strain in graphene from $0.75 \%$ (at $25{ }^{\circ} \mathrm{C}$ ) to $0.12 \%$.

In summary, prior to commercial use of Li-ion cells containing graphene-based anodes, a thermal pre-cycling step at an elevated temperature will yield a 35\% higher specific capacity even when operated at the same rate that was used for charging at room temperature.

Acknowledgements The financial support provided by the Natural Sciences and Engineering Research Council (NSERC) of Canada in the form of a Discovery Grant is gratefully acknowledged.

Open Access This article is distributed under the terms of the Creative Commons Attribution 4.0 International License (http://creativeco mmons.org/licenses/by/4.0/), which permits unrestricted use, distribution, and reproduction in any medium, provided you give appropriate credit to the original author(s) and the source, provide a link to the Creative Commons license, and indicate if changes were made.

\section{References}

1. Malard, L.M., Pimenta, M.A., Dresselhaus, G., Dresselhaus, M.S.: Raman spectroscopy in graphene. Phys. Reports 473, 51-87 (2009)

2. Liang, M.H., Zhi, L.J.: Graphene-based electrode materials for rechargeable lithium batteries. J. Mater. Chem. 19, 5871-5878 (2009)

3. Liu, C., Li, F., Ma, L.P., Cheng, H.M.: Advanced materials for energy storage. Adv. Mater. 22, E28-E62 (2010)

4. Bhattacharya, S., Riahi, A.R., Alpas, A.T.: In-situ observations of lithiation/de-lithiation induced graphite damage during electrochemical cycling. Scripta Mater. 64, 165-168 (2011)

5. Bhattacharya, S., Riahi, A.R., Alpas, A.T.: A transmission electron microscope study of crack formation and propagation in electrochemically cycled graphite electrode in lithium-ion cells. J. Power Sources 196, 8719-8727 (2011)

6. Bhattacharya, S., Alpas, A.T.: Micromechanisms of solid electrolyte interphase formation on electrochemically cycled graphite electrodes in lithium-ion cells. Carbon 50, 5359-5371 (2012)

7. Dahn, J.R., Zheng, T., Liu, Y., Xue, J.S.: Mechanisms for lithium insertion in carbonaceous materials. Science 270, 590-593 (1995)

8. Gerouki, A., Goldner, M.A., Goldner, R.B., Haas, T.E., Liu, T.Y., Slaven, S.: Density of states calculations of small diameter single graphene sheets. J. Electrochem. Soc. 143, L262-L263 (1996)

9. Pan, D.Y., Wang, S., Zhao, B., Wu, M.H., Zhang, H.J., Wang, Y., Jiao, Z.: Li storage properties of disordered graphene nanosheets. Chem. Mater. 21, 3136-3142 (2009)

10. Su, D.S., Schlögl, R.: Nanostructured carbon and carbon nanocomposites for electrochemical energy storage applications. Chem. Sus. Chem. 3, 136-168 (2010)

11. Sun, Y.Q., Wu, Q.O., Shi, G.Q.: Graphene based new energy materials. Energy Environ. Sci. 4, 1113-1132 (2011)

12. Banks, C.E., Brownson, D.B., Brownson, D.A.C., Kampouris, D.K.: An overview of graphene in energy production and storage applications. J. Power Sources 196, 4873-4885 (2011)

13. Pumera, M.: Graphene-based nanomaterials for energy storage. Energy Environ. Sci. 4, 668-674 (2011)
14. Guo, C.X., Wang, M., Chen, T., Lou, X.W., Li, C.M.: A hierarchically nanostructured composite of $\mathrm{MnO}_{2}$ /conjugated polymer/ graphene for high-performance Lithium ion batteries. Adv. Energy Mater. 1, 736-741 (2011)

15. Uthaisar, C., Barone, V.: Edge effects on the characteristics of Li diffusion in graphene. Nano Lett. 10, 2838-2842 (2010)

16. Yoo, E., Kim, J., Hosono, E., Zhou, H.S., Kudo, T., Honma, I.: Large reversible Li storage of graphene nanosheet families for use in rechargeable lithium ion batteries. Nano Lett. 8, 2277$2282(2008)$

17. Lian, P., Zhu, X., Liang, S., Li, Z., Yang, W., Wang, H.: Large reversible capacity of high quality graphene sheets as an anode material for lithium-ion batteries. Electrochim. Acta 55, 39093914 (2010)

18. Wu, Z.S., Ren, W., Xu, L., Li, F., Cheng, H.M.: Doped graphene sheets as anode materials with superhigh rate and large capacity for lithium ion batteries. ACS Nano 5, 5463-5471 (2011)

19. Han, S., Zhao, Y., Tang, Y., Tan, F., Huang, Y., Feng, X., Wu, D.: Ternary $\mathrm{MoS}_{2} / \mathrm{SiO}_{2} /$ graphene hybrids for high-performance lithium storage. Carbon 81, 203-209 (2015)

20. Wu, C., Lin, J., Chu, R., Zheng, J., Chen, Y., Zhang, J., Guo, H.: Reduced graphene oxide as a dual-functional enhancer wrapped over silicon/porous carbon nanofibers for high-performance lithium-ion battery anodes. J. Mater. Sci. 52, 7984-7996 (2017)

21. Guzman, R.C., Yang, J., Cheng, M.M.C., Salley, S.O., Ng, K.Y.S.: A silicon nanoparticle/reduced graphene oxide composite anode with excellent nanoparticle dispersion to improve lithium ion battery performance. J. Mater. Sci. 48, 4823-4833 (2013)

22. Aurbach, D., Markovsky, B., Rodkin, A., Levi, E., Cohen, Y.S., Kim, H.-J., Schmidt, M.: On the capacity fading of $\mathrm{LiCoO} 2$ intercalation electrodes: the effect of cycling, storage, temperature, and surface film forming additives. Electrochim. Acta 47, 4291-4306 (2002)

23. Aurbach, D., Talyosef, Y., Markovsky, B., Markevich, E., Zinigrad, E., Asraf, L., Gnanaraj, J.S., Kim, H.J.: Design of electrolyte solutions for $\mathrm{Li}$ and $\mathrm{Li}$-ion batteries: a review. Electrochim. Acta 50, 247-254 (2004)

24. Spotnitz, R., Franklin, J.: Abuse behavior of high-power, lithiumion cells. J. Power Sources 113, 81-100 (2003)

25. Smart, M.C., Ratnakumar, B.V., Whitacre, J., Whitcanack, L., Chin, K., Rodriguez, M., Surampudi, S.: The effect of high temperature exposure upon the performance of lithium ion cells. Seventeenth Annual Battery Conference on Applications and Advances. Proceedings of Conference (Cat. No.02TH8576). Long Beach, CA, pp. 53-58 (2002)

26. Smart, M.C., Ratnakumar, B.V., Whitacre, J.F., Whitcanack, L.D., Chin, K.B., Rodriguez, M.D., Zhao, D., Greenbaum, S.G., Surampudi, S.: Effect of electrolyte type upon the high-temperature resilience of lithium-ion cells. J. Electrochem. Soc. 152, A1096-A1104 (2005)

27. Tuinstra, F., Koenig, J.L.: Raman spectrum of graphite. J. Chem. Phys. 53, 1126-1130 (1970)

28. Pimenta, M.A., Dresselhaus, G., Dresselhaus, M.S., Cançado, L.G., Jorio, A., Saito, R.: Studying disorder in graphite-based systems by Raman spectroscopy. Phys. Chem. Chem. Phys. 9, 1276-1290 (2007)

29. Ferrari, A.C.: Raman spectroscopy of graphene and graphite: disorder, electron-phonon coupling, doping and nonadiabatic effects. Solid State Commun. 143, 47-57 (2007)

30. Jaber-Ansari, L., Puntambekar, K.P., Tavassol, H., Yildirim, H., Kinaci, A., Kumar, R., Saldaña, S.J., Gewirth, A.A., Greeley, J.P., Chan, M.K.Y., Hersam, M.C.: Defect evolution in graphene upon electrochemical lithiation. ACS Appl. Mater. Interfaces. 6, 17626-17636 (2014) 
31. Vidano, R.P., Fishbach, D.B., Willis, L.J., Loehr, T.M.: Observation of Raman band shifting with excitation wavelength for carbons and graphites. Solid State Commun. 39, 341-344 (1981)

32. Yoon, S.M., Choi, W.M., Baik, H., Shin, H.J., Song, I., Kwon, M.S., Bae, J.J., Kim, H., Lee, Y.H., Choi, J.Y.: Synthesis of multilayer graphene balls by carbon segregation from nickel nanoparticles. ACS Nano 6, 6803-6811 (2012)

33. Radhakrishnan, G., Cardema, J.D., Adams, P.M., Kim, H.I., Foran, B.: Fabrication and electrochemical characterization of single and multi-layer graphene anodes for lithium-ion batteries. J. Electrochem. Soc. 159, A752-A761 (2012)

34. Maire, P., Evans, A., Kaiser, H., Scheifele, W., Novák, P.: Colorimetric determination of lithium content in electrodes of lithiumion batteries. J. Electrochem. Soc. 155, A862-A865 (2008)

35. Peled, E.: The electrochemical behavior of alkali and alkaline earth metals in nonaqueous battery systems - the solid electrolyte interphase mode. J. Electrochem. Soc. 126, 2047-2051 (1979)

36. Vargas, Ó., Caballero, Á., Morales, J., Castellón, E.R.: Contribution to the understanding of capacity fading in graphene nanosheets acting as an anode in full Li-ion batteries. ACS Appl. Mater. Interfaces. 6, 3290-3298 (2014)

37. An, S.J., Li, J., Daniel, C., Mohanty, D., Nagpure, S., Wood III, D.L.: The state of understanding of the lithium-ion-battery graphite solid electrolyte interphase (SEI) and its relationship to formation cycling. Carbon 105, 52-76 (2016)

38. Winter, M., Appel, W.K., Evers, B., Hodal, T., Möller, K.C., Schneider, I., Wachtler, M., Wagner, M.R., Wrodnigg, G.H., Besenhard, J.O.: Studies on the anode/electrolyte interface in lithium ion batteries. Monatsh. Chem. 132, 473-486 (2001)

39. Das, A., Chakraborty, B., Sood, A.K.: Raman spectroscopy of graphene on different substrates and influence of defects. Bull. Mater. Sci. 31, 579-584 (2008)

40. Wang, G., Shen, X., Yao, J., Park, J.: Graphene nanosheets for enhanced lithium storage in lithium ion batteries. Carbon $\mathbf{4 7}$, 2049-2053 (2009)

41. Kokai, F., Sorin, R., Chigusa, H., Hanai, K., Koshio, A., Ishihara, M., Koga, Y., Hasegawa, M., Imanishi, N., Takeda, Y.: Ultrasonication fabrication of high quality multilayer graphene flakes and their characterization as anodes for lithium ion batteries. Diam. Relat. Mater. 29, 63-68 (2012)
42. Bhattacharya, S., Riahi, A.R., Alpas, A.T.: Thermal cycling induced capacity enhancement of graphite anodes in lithium-ion cells. Carbon 67, 592-606 (2014)

43. Bhattacharya, S., Riahi, A.R., Alpas, A.T.: Electrochemical cycling behaviour of lithium carbonate $\left(\mathrm{Li}_{2} \mathrm{CO}_{3}\right)$ pre-treated graphite anodes-SEI formation and graphite damage mechanisms. Carbon 77, 99-112 (2014)

44. Novák, P., Joho, F., Lanz, M., Rykart, B., Panitz, J.C., Alliata, D., Kötz, R., Haas, O.: The complex electrochemistry of graphite electrodes in lithium-ion batteries. J. Power Sources 97-98, 39-46 (2001)

45. Reich, S., Jantoljak, H., Thomsen, C.: Shear strain in carbon nanotubes under hydrostatic pressure. Phys. Rev. B 61, R13389_ R13392 (2000)

46. Thomsen, C., Reich, S., Ordejon, P.: Ab initio determination of the phonon deformation potentials of graphene. Phys. Rev. B 65 , 073403/1-073403/3 (2002)

47. Ding, F., Ji, H., Chen, Y., Herklotz, A., Dörr, K., Mei, Y., Rastelli, A., Schmidt, O.G.: Stretchable graphene: a close look at fundamental parameters through biaxial straining. Nano Lett. 10, 3453-3458 (2010)

48. Cheng, Y.C., Zhu, Z.Y., Huang, G.S., Schwingenschlögl, U.: Gruneisen parameter of the $\mathrm{G}$ mode of strained monolayer graphene. Phys. Rev. B 83, 115449 (2011)

49. Politano, A., Chiarello, G.: Probing the Young's modulus and Poisson's ratio in graphene/metal interfaces and graphite: a comparative study. Nano Res. 8, 1847-1856 (2015)

50. Panitz, J.C., Joho, F., Novak, P.: In situ characterization of a graphite electrode in a secondary lithium-ion battery using Raman microscopy. Appl. Spectrosc. 53, 1188-1199 (1999)

51. Qi, Y., Harris, S.J.: In situ observation of strains during lithiation of a graphite electrode. J. Electrochem. Soc. 157, A741-A747 (2010)

52. Leng, F., Tan, C.M., Pecht, M.: Effect of temperature on the aging rate of $\mathrm{Li}$ ion battery operating above room temperature. Scientific Reports 5(12967), 1-12 (2015)

53. Shi, S., Qi, Y., Li, H., Hector Jr., L.G.: Defect thermodynamics and diffusion mechanisms in $\mathrm{Li}_{2} \mathrm{CO}_{3}$ and implications for the solid electrolyte interphase in Li-ion batteries. J. Phys. Chem. C 117, 8579-8593 (2013) 